\title{
ANALISA JUMLAH KROMOSOM IKAN MAS KOKI (Carrasius auratus) TETRAPLOID YANG DIHASILKAN DENGAN METODE KEJUTAN PANAS
}

\author{
ANALYSES OF CHROMOSOM NUMBERS OF TETRAPLOID GOLDFISH \\ (Carrasius auratus) PRODUCED BY HEAT SHOCKING METHOD
}

\author{
Rustidja $^{*}$
}

\begin{abstract}
The objectives of research was to analyses the chromosome numbers of tetraploid goldfish (Carassius auratus) produced by heat shocking method. The tetraploidy was carried out 29 minutes after fertilization of eggs by heat shocking for 1.5 minutes at $40^{\circ} \mathrm{C}$. The chromosome number was analyzed with the modus of chromosomes.

The results indicated that 1) the diploid control of goldfish has $100.28 \% \pm 0.0982$ chromosom with modus numbers of 100 , and the tetraploid goldfish has $199.94 \pm 0.982$ chromosomes with number of modus at 200. 2) The effectiveness of the heat shocking method in goldfish for tetraploidy was $46.60 \%$.

The hatching rate of diploid control $(65.068 \% \pm 0.52 \%)$ was significantly diferent with that of tetraploid fish $(24.53 \% \pm 1.649 \%)$. In addition, the survival rate of diploid controls $(86.875 \% \pm$ 6.287). was significantly different with that of tetraploid goldfish $(34.274 \% \pm 19.289 \%)$ and the specific growth rates of diploid controls $(5,104 \pm 0,074)$ was not significantly diferent that of with tetraploid fish $(3.982 \pm 0.011)$.
\end{abstract}

Key words : Carrasius auratus, chromosoms, heat shocking method, tetraploid

\section{Pengantar}

Poliploidi dengan jumlah kromosom genap, seperti tetraploid dengan $4 \mathrm{n}$ kromosom lebih diarahkan untuk menghasilkan triploid buatan dengan cara menyilangkan antara spesies diploid dengan tetraploid. Hal ini dimungkinkan karena individu tetraploid merupakan individu yang fertil juga mempunyai laju pertumbuhan yang lebih baik bila dibandingkan dengan spesies diploid (Suryo, 1990).

Sejalan dengan kemajuan bioteknologi, dalam dekade terakhir ini mulai dikembangkan model-model manipulasi kromosom sebagai jawaban masalah yang dihadapi produsen ikan dalam peningkatan hasil produksinya.

Menurut Rustidja (1991), hal penting dalam aplikasi kromosom adalah penentuan jenis ikan yang akan digunakan, tujuan manipulasi, teknik manipulasi yang digunakan, dan bagaimana menguji hasil produksi tersebut.

Model-model manipulasi kromosom yang telah dicobakan meliputi androgenesis, ginogenesis, triploidisasi, dan tetraploidisasi. Pada ikan teleostei, manipulasi kromosom dapat digunakan untuk memproduksi populasi ikan tetraploid dan fully inbreed lines.

Selanjutnya ditambahkan pula bahwa tetraplodisasi sangat efektif untuk memproduksi populasi ikan tetraploid itu sendiri yaitu dengan cara mengawinkan diantara mereka sendiri sehingga dapat dihasilkan ikan tetraploid seperti induknya. Di samping untuk tujuan di atas, ikan tetraploid diproduksi guna menghasilkan ikan triploid dengan cara menyilangkan ikan tetraploid (4n) dengan ikan normal diploid.

\footnotetext{
") Staf Pengajar Fakultas Perikanan Universitas Brawijaya, Jalan M.T.Haryono 161 Malang, Jawa Timur
} 
Menurut Suryo (1990), pada individu tetraploid mempunyai kemampuan di dalam pembelahan sel yang jauh lebih tinggi bila dibandingkan dengan ikan normal diploid sehingga ikan tetraploid akan mempunyai jumlah sel yang lebih banyak jika dibandingkan dengan ikan mas koki normal. Hal ini berhubungan dengan tingkat pertumbuhan pada ikan tetraploid yang jauh lebih besar dibanding dengan ikan diploid secara umum.

Untuk menghasilkan ikan tetraploid di dalam telur, dapat diperoleh dengan kejutan suhu setelah peloncatan polar body II, sehingga telur yang mempunyai $2 n$ kromosom akan mengalami penggandaan menjadi $4 \mathrm{n}$ kromosom. Teknik kejutan suhu dapat dilakukan dengan 2 cara yaitu, kejutan panas (heat shock) dan kejutan dingin (cold shock).

Untuk mendapatkan ikan tetraploid maka kejutan panas dilakukan setelah 29 menit telur terbuahi dan direndam dalam air panas bersuhu $40^{\circ} \mathrm{C}$ selama 1,5 menit. Hal tersebut merupakan kondisi efektif untuk menghasilkan tetraploid pada ikan mas koki (Carassius auratus) (Carman, et al.,1991).

Penelitian ini dilaksanakan untuk membuktikan efektifitas kejutan panas yang selama ini diterapkan dalam manipulasi jumlah kromosom ikan mas koki guna peningkatan produksi perikanan.

Tujuan dari penelitian ini adalah untuk mengetahui jumlah kromosom ikan hias mas koki diploid dan tetraploid, mengetahui efektifitas metode kejutan panas dalam menghasilkan ikan tetraploid, dan mengetahui perbandingan laju penetasan, laju kelulushidupan dan pertumbuhan larva ikan sampai umur 28 hari pada ikan diploid dan tetraploid.

\section{Bahan dan Metode}

Peralatan yang dipergunakan meliputi alat induced spawning dan alat kejutan suhu, sedangkan bahan-bahan yang diperguna- kan adalah induk mas koki yang matang gonad, hormon pituitari ikan mas segar, $\mathrm{NaCl}$ fisiologis $0,9 \%$, larutan $\mathrm{NaCl}$ dan urea, colchicine $0,007 \%, \mathrm{KCl} 0,075 \mathrm{M}$, ethyl alkohol absolut, asam asetat glasial, giemsa, buffer phosphat $\mathrm{pH} 6,8$, kuning telur ayam, enthelan, minyak immersi, kertas tissue, aquadest dan methylene blue.

Metode penelitian adalah eksperimen dengan satu buah perlakuan dan kontrol, yaitu pemberian kejutan panas selama 1,5 menit pada suhu $40^{\circ} \mathrm{C}$ yang dilakukan 29 menit setelah pembuahan. Untuk mengetahui pengaruh perlakuan jumlah kromosomnya dibandingkan dengan kontrol. Analisis data dilakukan dengan uji-t.

\section{a. Induced spawning}

Induk betina ikan mas koki yang matang gonad disuntik dengan $3 \mathrm{mg}$ cPG basah $/ \mathrm{Kg}$ BW atau dengan dosis 1,5 secara intramuscular pada otot punggung, yaitu jarum disisipkan antara sisik lalu ditusukkan ke dalam otot. Setelah $10-12$ jam dari penyuntikan induk ikan betina diambil dari akuarium, dan mulai melakukan stripping untuk mengeluarkan telur. Menampung telur dalam baskom kecil dan kering.

\section{b. Pemberian kejutan panas}

Teknik kejutan panas menggunakan metode Rustidja (1991), yaitu telur yang telah dibuahi dengan sperma segar ditaruh dalam baskom plastik, pada saat 29 menit setelah pembuahan telur dimasukan ke dalam air bersuhu $\pm 40^{\circ} \mathrm{C}$ selama 1,5 menit, telur dipindahkan, diinkubasi pada akuarium penetasan dengan suhu $27^{\circ} \mathrm{C}$.

\section{c. Pemeliharaan larva hasil tetraploid}

Telur yang menetas dengan kondisi normal dipelihara dalam akuarium. Pakan yang diberikan adalah suspensi kuning telur pada larva berumur 5 hari. Larva yang berumur lebih 7-14 hari, mulai di- 
berikan pakan alami berupa Daphnia atau jentik nyamuk.

\section{d. Pembuatan preparat kromosom}

Pada penelitian ini pembuatan preparat kromosom menggunakan metode perendaman Klingerman dan Bloom, yaitu larva ikan direndam dalam $50 \mathrm{~mL}$ larutan colchicine selama 6 - 7 jam, ikan dibunuh, masing masing ikan digerus sampai halus, jaringan dimasukkan ke dalam larutan $0,075 \mathrm{M} \mathrm{KCl}$ selama 90 menit, kemudian jaringan direndam ke dalam larutan carnoy I dan II, masing masing selama 30 menit, jaringan ditempatkan dalam gelas arloji, ditetesi carnoy dan dicacah, suspensi yang diperoleh diteteskan pada obyek glass yang bersih sebanyak 1 - 2 tetes, dan dikering anginkan, preparat yang diperoleh diwarnai dengan pewarna geimsa $10 \%$ $30 \%$ selama 10 - 30 menit, sisa pewarna dicuci dengan air mengalir dan dikering anginkan, kemudian tutup gelas benda dengan enthelan, preparat diamati di bawah mikroskop dengan pembesaran 400 - 1000 kali.

\section{Analisa data}

Pada penelitian ini menggunakan 2 perlakuan, yaitu perlakuan $A$ dan perlakuan B. Perlakuan A adalah kontrol tanpa kejutan suhu dan perlakuan B dengan kejutan suhu pada telur yang telah dibuahi untuk menghasilkan individu tetraploid.

Penghitungan jumlah kromosom ikan hias mas koki diploid dan tetraploid diperoleh dari hasil perlakuan yang diberikan, dilakukan dengan cara mengambil 10 ekor ikan sampel dari masing masing ulangan perlakuan, dimana setiap ikan sampel menghasilkan 1 preparat kromosom yang umumnya dapat ditemukan 8 sebaran metafase. Jumlah kromosom ditentukan dengan menghitung jumlah maksimal dan dari nilai yang sering muncul dari sebaran metafase.
Data yang diperoleh dianalisa secara deskriptif yang disusun dalam bentuk tabel dan gambar.

Metode untuk mengetahui pengaruh perlakuan terhadap laju penetasan, kelulushidupan, dan laju pertumbuhan larva yang dihasilkan digunakan uji $t$. Pada dasarnya uji tersebut membedakan 2 perlakuan dengan membendingkan $t$ hitung dengan $t$ tabel $5 \%$ dan $1 \%$. Nilai $t$ hitung diperoleh dengan menggunakan rumus sebagai berikut :

$$
\text { thitung }=(\overline{\mathrm{A}}-\overline{\mathrm{B}}) \sqrt{\frac{n(n-1)}{J K A+J K B}}
$$

\section{Parameter uji}

\section{a. Jumlah kromosom}

Penentuan jumlah kromosom berdasarkan nilai yang paling sering muncul atau mempunyai frekuensi yang paling tinggi dari sebaran metafase yang ditemukan.

\section{b. Laju penetasan}

$$
\mathrm{HR}=\frac{a}{a+b+c} \times 100 \%
$$

Keterangan :

$\mathrm{a}=$ jumlah larva yang menetas dengan normal

$\mathrm{b}=$ jumlah larva yang menetas tapi cacat

$\mathrm{C}=$ jumlah telur yang tidak menetas

c. Kelulushidupan $t_{0}$ sampai $t_{28}$

$$
S R=\left(N_{t} / N_{0}\right) \times 100 \%
$$

dimana,

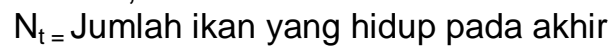
penelitian

$\mathrm{N}_{0}=$ Jumlah ikan yang hidup pada awal penelitian 


\section{d. Laju petumbuhan sesaat}

$$
\mathrm{g}=\frac{\ln W t-\ln W 0}{t}
$$

Keterangan :

$\mathrm{Wt}=$ berat rata rata ikan pada waktu tertentu

Wo $=$ berat rata rata ikan pada $\mathrm{t}=0$

$\mathrm{t}=$ waktu (hari)

$\mathrm{g}$ = laju pertumbuhan sesaat

\section{Hasil dan Pembahasan}

\section{Analisis jumlah kromosom}

Hasil yang diperoleh dari perhitungan jumlah kromosom ikan mas koki diploid dan tetraploid didapatkan sebaran metafase yang sangat kecil, yaitu kurang dari 8 sebaran pada setiap ring preparat. Dari 30 preparat ikan mas koki diploid, ternyata ditemukan beberapa yang tidak terdapat sebaran metafase, demikian juga dengan preparat ikan mas koki tetraploid. Hal ini dimungkinkan karena pada saat perlakuan perendaman colchicine kondisi ikan mengalami stres. Kondisi stres terjadi akibat proses aklimatisasi yang berjalan kurang sempurna, dan kondisi ini mengakibatkan terganggunya metabolisme tubuh sehingga fungsi colchicine ini akan berkurang. Dari 30 preparat ikan mas koki diploid dapat diketahui modus dari sebaran metafasenya adalah 100,28 $\pm 0,0982$. Hal ini sesuai dengan hasil penelitian yang dilakukan oleh Chingjiang et al. (1986) yang menyatakan bahwa kromosom diploid ikan mas koki adalah 100. Dari 30 preparat ikan mas koki tetraploid ditemukan bahwa $66 \%$ preparat mempunyai modus pada angka 100 (berada pada kisaran kromosom diploid), preparat yang mempunyai modus sekitar angka 200 (berada pada kisaran angka tetraploid) sebanyak $33,90 \%$ sedangkan preparat yang tidak ditemukan sebaran kromosom sebanyak $26,667 \%$. Sehingga penelitian dengan perlakuan kejutan suhu pada menit ke-29 setelah fertilisasi dengan suhu kejutan sebesar $40^{\circ} \mathrm{C}$ selama 1,5 menit ini kurang efektif. Menurut Carman (1992), bahwa dalam pembuatan ikan tetraploid ditentukan pada kondisi optimum saat membuat tetraploid, waktu fertilisasi akhir, suhu kejutan dan lama kejutan. Kromosom ikan mas koki diploid dan tetraploid dapat dilihat pada Gambar 1.

\section{A}

B

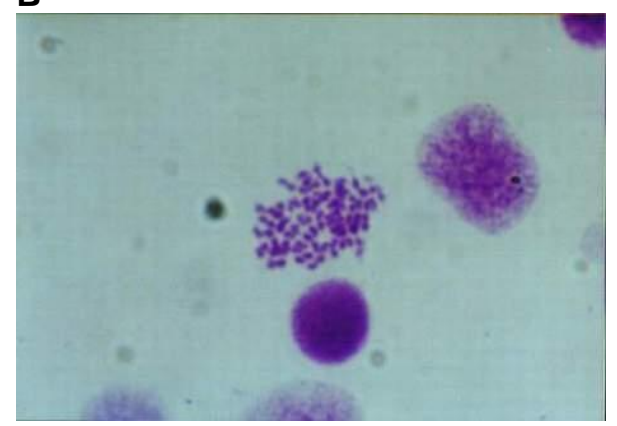

Gambar 1. Kromosom ikan mas koki diploid dan tetraploid dengan pembesaran 1000 x. A, diploid; $B$, tetraploid

Penentuan jumlah kromosom dilakukan berdasarkan nilai yang sering muncul atau yang mempunyai frekuensi paling tinggi (modus) dari sebaran metafase yang ditemukan pada preparat kromosom. Dalam pembuatan preparat kromosom terdapat beberapa faktor yang perlu diperhatikan. Faktor-faktor tersebut meliputi praperlakuan dengan colchicine, larutan hipotonis, larutan fiksasi, pewarnaan serta sumber jaringan yang digunakan. Praperlakuan dengan colchicine menurut Gunarso (1986), pada prinsipnya berguna untuk mengubah viskositas pada sitoplasma sehingga menyebabkan terjadinya perusakan benang spindel dan 
akhirnya pembelahan sel pada metafase terhenti. Pemberian colchicine ini harus tepat baik dosis maupun waktu inkubasinya. Colchicine hanya berpengaruh pada sel yang sedang aktif membelah, oleh karena itu perlakuan yang efektif adalah apabila diberikan pada sel-sel yang sedang aktif membelah. Waktu inkubasi yang terlalu singkat akan menghasilkan sedikit sebaran kromosom (Carman, 1992). Dan sebaliknya, menurut Denton dan Howell (1969), pemberian colchicine yang terlalu lama akan menyebabkan berkontraksinya kromosom. Pemberian colchicine dengan dosis 0,007 - 0,01\% (w/v) dan waktu inkubasi selama 6-7 jam dihasilkan sebaran kromosom yang cukup baik, tetapi kadang tidak ditemukan sebaran kromosom sama sekali pada beberapa individu. Hal ini disebabkan pengaruh metabolisme individu selama perlakuan. Bila ikan dalam keadaan sehat (tidak stres) maka colchicine akan bereaksi dengan baik, sebaliknya bila ikan yang digunakan dalam keadaan sakit (stres) akibat penyuntikan atau perendaman, metabolisme tubuh akan terganggu sehingga fungsi colchicine semakin berkurang.

Perendaman jaringan dalam larutan hipotonis sangat menentukan sebaran kromosom yang dihasilkan. Perendaman dimaksudkan untuk membesarkan sel sehingga kromosom menyebar dengan baik. Menurut Kligerman dan Bloom (1977), lama perendaman menggunakan $\mathrm{KCl}$ 0,075 M adalah selama 20 - 30 menit. tetapi pada penelitian ini digunakan perendaman selama 90 - 100 menit. Menurut Carman (1992), lama perendaman dalam larutan hipotonis dapat dimodifikasi untuk menghasilkan sebaran yang baik.

Pewarnaan preparat kromosom menggunakan giemsa 10 - 15\% selama 20 menit. Hasil yang diperoleh, kromosom berwarna merah dan pucat. Bervariasinya warna pada kromosom diduga karena adanya pengaruh suhu pada saat pewarnaan fiksatif jaringan yang digunakan sebelumnya, $\mathrm{pH}$ dan kekuatan ion pewarna.

Dalam preparat yang ada ternyata ditemukan adanya jumlah kromosom yang kurang atau lebih dari modus. Hal ini disebabkan adanya kromosom yang terpisah dari kelompoknya sehingga jumlah satu set kromosomnya berkurang atau ada tambahan dari kromosom lain yang terpisah dari kelompoknya sehingga jumlahnya berlebih. Selain itu kurangnya jumlah kromosom dari modus diduga karena adanya penumpukan kromosom dan renggangnya sebaran kromosom akibat perendaman jaringan dalam larutan hipotonis yang tidak tepat. Hal ini sesuai dengan pernyataan Al-Sabti (1985), bahwa variasi jumlah kromosom dikarenakan dari teknik preparasi kromosom, hilangnya kromosom saat pembuatan preparat atau kebetulan selnya aneuploid.

Lebih jauh dapat dikatakan bahwa, perubahan jumlah kromosom disebabkan oleh adanya peristiwa euploidi atau aneuploidi. Euploidi adalah suatu kondisi tidak normal, yaitu beberapa set kromosom menurun atau meningkat jumlahnya. Aneuploidi adalah suatu ketidaknormalan di dalam jumlah satu set kromosom atau lebih,dan aneuploidi lebih disebabkan oleh kesalahan pemisahan satu pasang kromosom saat pembelahan meiosis (non disjunction).

Non disjunction disebabkan adanya kegagalan dari satu pasang kromosom homolog atau lebih untuk melakukan pemisahan secara tepat selama pembelahan sel. Jika non disjunction terjadi pada pembelahan meiosis maka semua sel pada individu akan mengalami perubahan dalam jumlah kromosom. Tetapi apabila non disjunction terjadi pada pembelahan mitosis maka hanya beberapa sel somatis saja yang mengalami aneuploid (De Robertis et al., 1981). 


\section{Laju penetasan}

Dari penelitian yang dilakukan, diperoleh data laju penetasan dan kelulushidupan seperti yang terlihat pada Tabel 1 .

Tabel 1. Rata-rata persentase laju penetasan dan kelulushidupan ikan mas koki (Carassius auratus) diploid dan tetraploid.

\begin{tabular}{|c|r|r|r|r|}
\hline \multirow{2}{*}{ Ulangan } & \multicolumn{2}{|c|}{ Laju penetasan } & \multicolumn{2}{c|}{ Kelulushidupan } \\
\cline { 2 - 5 } & Diploid & Tetraploid & Diploid & Tetraploid \\
\hline I & 65,041 & 24,413 & 79,375 & 28,846 \\
II & 65,602 & 24,093 & 83,521 & 18,279 \\
III & 64,563 & 5,079 & 91,729 & 55,696 \\
\hline Rerata & 65,068 & 24,528 & 84,875 & 34,274 \\
\hline
\end{tabular}

Perhitungan persentase pertumbuhan didasarkan pada jumlah sampel telur yang digunakan, baik yang menggunakan larva normal, larva cacat maupun telur yang tidak menetas. Dari data di atas terlihat nilai laju penetasan tetraploid lebih kecil dari pada ikan diploid, yaitu sebesar $65,068 \% \pm 0,62$ untuk perlakuan diploid dan $24,528 \%+1,695$ untuk perlakuan tetraploid. Hal ini dapat disebabkan pada perlakuan tetraploid mempunyai persentase larva cacat yang lebih besar dari pada larva cacat pada ikan diploid. Larva yang cacat ini dapat disebabkan karena per-lakuan kejutan panas yang diberikan, seperti yang dijelaskan oleh Solar et al. (1984) dalam Najmushabah (1993).

Hasil pengamatan menunjukkan bahwa di samping larva normal juga ditemukan larva cacat. Hal ini dijelaskan oleh Solar et al.(1984) dalam Najmushabah (1993) bahwa individu-individu yang mendapat perlakuan kejutan suhu panas memiliki penyimpangan bentuk tubuh/abnormalitas serta kematian yang tinggi dibandingkan dengan kontrol normal. Dustin (1977) dalam Gevai et al. (1980) bahwa kejutan suhu dan tekanan mengakibatkan rusaknya mikrotubulus yang membentuk spindel selama pembelahan.

Larva cacat ini bila diamati secara morfologis mempunyai ciri-ciri ekor dan vertebranya membengkok, serta kelainan pada kepala yang terlihat lebih besar (tidak seimbang dengan ukuran tubuh). Menurut Gervai et al. (1980), larva-larva yang haploid akan mempunyai ciri ciri tersebut, maka larva yang diamati diperkirakan berkromosom haploid.

\section{Kelulushidupan}

Nilai kelulushidupan dari 3 induk dapat dilihat pada Tabel 1, dimana nilai kelulushidupan dari 3 induk ini bervariasi, tetapi pada umumnya nilai kelulushidupan ikan diploid lebih besar dari ikan tetraploid. Nilai rata rata persentase kelulushidupan ikan diploid adalah $84,875 \% \pm 6,287$ dan ikan tetraploid adalah $34,274 \% \pm 5,289$. Hal ini karena persentase larva cacat yang kemungkinan berkromosom haploid ini lebih banyak dijumpai pada ikan tetraploid dari pada ikan diploid. Kematian larva selain disebabkan oleh adanya larva cacat, juga dapat disebabkan oleh faktor lain seperti kualitas air media, serangan jamur, serta pemberian pakan yang kurang sesuai. Kematian tertinggi terdapat pada saat telur belum menetas dan juga saat pertama kali larva mencari makanan di luar.

\section{Laju pertumbuhan}

Faktor-faktor yang mempengaruhi pertumbuhan antara lain, jumlah dan ukuran pakan, kualitas air, umur dan ukuran ikan serta kematangan gonad (Effendi, 1990).

Dalam penelitian ini, pertumbuhan pada ikan diploid dan tetraploid dihitung selama 28 hari sebagai laju pertumbuhan sesaat. Data laju pertumbuhan dari ikan mas koki diploid dan tetraploid dapat dilihat pada Tabel 2.

Tabel 2. Laju pertumbuhan ikan mas koki diploid dan tetraploid yang dihitung beratnya selama 28 hari.

\begin{tabular}{|c|c|c|}
\hline Ulangan & Diploid & Tetraploid \\
\hline 1 & 1,872 & 1,204 \\
2 & 1,846 & 1,392 \\
3 & 1,386 & 1,386 \\
\hline Rerata & 1,701 & 1,327 \\
\hline
\end{tabular}


Dari data di atas terlihat bahwa laju pertumbuhan absolut ikan diploid mempunyai rata rata yang lebih tinggi daripada ikan tetraploid, yaitu sebesar 5,104 untuk ikan diploid dan 3,982 untuk ikan tetraploid. Tetapi dengan uji-t dapat diketahui bahwa laju petumbuhan pada ikan diploid dan tetraploid tidak menunjukkan perbedaan nyata. Hal ini dapat disebabkan oleh faktor umur, umur yang masih muda laju pertumbuhan pada individu diploid dan tetraploid kemungkinan akan sama, tetapi akan berbeda setelah ikan mengalami perkembangan gonad.

\section{Kualitas air}

Pengukuran kualitas air media meliputi oksigen terlarut, suhu, dan $\mathrm{pH}$. Telur dan larva yang dihasilkan dipelihara dalam bak bak dengan sistem resirkulasi, air terus mengalir dan berganti dengan air yang baru. Dengan sistem resirkulasi ini air pada bak-bak percobaan mempunyai kualitas yang relatif sama.

Suhu rata-rata harian pukul $06.00-16.00$ berkisar antara $22-24^{\circ} \mathrm{C}$. Menurut Susanto (1987), suhu yang optimum untuk pemeliharaan ikan mas koki adalah antara $20-25^{\circ} \mathrm{C}$. Kandungan oksigen terlarut pada air media berkisar antara 7,2 7,5 ppm.Menurut Zonneveld et a.I (1991), kadar oksigen dalam budidaya ikan maskoki tidak boleh kurang dari 3 ppm. Susanto (1987) menyatakan pH optimum untuk ikan maskoki berkisar 7-8. Sebagai parameter penunjang, kualitas air selama penelitian masih berada pada kisaran yang layak bagi kelangsungan hidup dan pertumbuhan larva dan benih ikan maskoki.

\section{Kesimpulan dan Saran}

\section{Kesimpulan}

1. Perlakuan tetraploid dengan kejutan panas pada menit ke-29 setelah pembuahan selama 1,5 menit dengan kejutan panas pada $40^{\circ} \mathrm{C}$ meng- hasilkan persentase tetraploid sebesar $33,9 \%$

2. Nilai rata rata laju penetasan ikan diploid lebih besar dari pada ikan tetraploid, yaitu $65,068 \% \pm 0,52$ untuk ikan diploid dan $24,528 \% \pm 1,649$ untuk ikan tetraploid

3. Nilai kelulushidupan ikan diploid $(84,875 \% \pm 6,287)$ lebih besar daripada ikan tetraploid $(34,274 \%)$

4. Nilai rata rata laju pertumbuhan sesaat ikan tetraploid $(5,104 \pm 0,074)$ lebih besar dibandingan ikan diploid $(3,982$ $\pm 0,011$ )

Saran

1. Identifikasi ikan poliploid sebaiknya dilakukan uji nukleolus terlebih dahulu untuk memudahkan identifikasi

2. Perlu dilakukan induksi tetraploid dengan waktu kejutan, lama kejutan, dan saat kejutan yang berbeda untuk menghasilkan ikan tetraploid yang lebih tinggi.

\section{Daftar Pustaka}

Al-Sabti. 1985. Chromosomal studies by blood leucocyte culture technique on three salmonids from Yugoslavian waters. Fish Biol, $26: 5-12$

Carman O., Takashi and T. Fumio, 1991. Estimation of effective management condition for induction of triploidy in goldfish, Carasius auratus. J. of the Tokyo Univ. of Fisheries, 78 (2) : 127-135.

-, 1992. Variation in the maximum number of nucleoli Departement Aquatic BioSciences. Tokyo Univ. of Fisheries. Tokyo.

Chingjiang, W., Y. Yuzhen and C. Rongde. 1986. Genom manipulation in carp. (Cyprinus 
carpio L.) Aquaculture. 54 : 57 61.

Denton, T.E., and W.M.Howell, 1965. A technique for obtain chromosome from the scale epithelium of fucos fishes. Dept. of Biology Stanford Univ. of Alabama. 392 $-393$.

De Robertis, E.D. Pand and E.M.F. De Robertis, 1981. Essential of cell and mollecular biology. Saunders Collage Publ. HoltSaunders Tokyo. $395 \mathrm{p}$.

Effendi, H. 1990. Memelihara mas koki di akuarium. Kanisius. Yogyakarta. 151 hal.

Gervai J.S., A. Nagy, S. Peter, L. Hoorvath and V. Cassani. 1980. Induced triploidy in carp. J. Fish Biol. 17 : 667 - 671 .
Gunarso, W. 1986. Penuntun praktikum sitogenetika. P.A.U. IPB Bogor. 14-16 p.

Najmushabah., F. 1993. Pengaruh kejutan panas terhadap keberhasilan triploidy ikan lele (Clarias batrachus L). Fakultas Perikanan IPB.

Rustidja. 1991. Aplikasi manipulasi kromosom pada program pembenihan ikan. Makalah pada kongres ilmu pengetahuan nasional V di Jakarta, September 1991. 23 p.

Suryo. 1990. Sitogenetika. Gajah Mada Univ. Press. Yogyakarta. 442 p.

Susanto, H. 1987. Budidaya ikan di pekarangan. PT. Penebar Swadaya. Jakarta. 112 p. 